$\mathrm{A} \int_{\text {ars }} \mathrm{H}$

Article history :

Received : 30.12.2015

Revised : 11.04 .2016

Accepted : 23.04.2016

Members of the Research Forum

Associated Authors:

${ }^{1}$ Department of Vegetable Crops,

Horticultural College and Research

Institute, Tamil Nadu Agricultural

University, COIMBATORE (T.N.)

INDIA
Author for correspondence : M. PRABHU

Department of Vegetable Crops, Horticultural College and Research Institute, Tamil Nadu Agricultural University, COIMBATORE (T.N.) INDIA

Email : prabhuhort@gmail.com
THEASIAN JOURNALOF HORTICULTURE

Volume 11 | Issue 1 | June, 2016 | 47-5

Visit us -www.researchjournal.co.in

\title{
Impact of drip fertigation on leaf nutrient status and yield attributes in chilli (Capsicum annuum L.) Hybrid $\mathrm{CCH} 1$
}

M. PRABU, S. NATARAJAN ${ }^{1}$, L. PUGALENDHI ${ }^{1}$ AND R. MURUGESAN ${ }^{1}$

ABSTRACT : A field experiment to study the soil, plant nutrient status and yield of hybrid chilli (Capsicum annum L.) $\mathrm{CCH} 1$ as influenced by fertigation of $\mathrm{N}$ and $\mathrm{K}$ fertilizers was carried out during 2010-12. The experiment was laid out in Randomized Block Design with three replications and the treatments included were three levels $(125,100$ and $75 \%$ recommended dose) each of water soluble and straight fertilizers. The soil nutrient parameters viz., available soil nitrogen, phosphorus, potassium content and plant nutrient parameters viz., leaf nitrogen, phosphorus and potassium were recorded. The yield parameters like number of fruits per plant, fruit girth, and fruit weight, green fruit yield per plant and per plot were also recorded. The study revealed that the soil and plant nutrient contents in general increased up to 120 days and then declined. Among the several treatments, NPK @100 per cent recommended dose of water soluble fertilizers along with liquid biofertilizers registered the highest value for the soil, plant nutrient content and yield parameters.

KEY WORDS : Fertigation, Soil, Leaf nutrients, Water soluble fertilizers, Straight fertilizers, Yield

HOW TO CITE THIS ARTIClE : Prabu, M., Natarajan, S., Pugalendhi, L. and Murugesan, R. (2016). Impact of drip fertigation on leaf nutrient status and yield attributes in chilli (Capsicum annuum L.) Hybrid CCH1. Asian J. Hort., 11(1) : 47-51, DOI : 10.15740/HAS/TAJH/11.1/47-51. 